Open Access

\title{
A failure innovation strategy of acquisition during excess capacity: financial approach based on case study at the state-owned cement holding PT Semen Indonesia (Persero) Tbk
}

\author{
Effnu Subiyanto (1)
}

\author{
Correspondence: effnu@yahoo.com \\ Department of Postgraduate \\ School, Faculty of Magister \\ Management, Widya Mandala \\ Surabaya Catholic University \\ (UKWM), Surabaya, Indonesia
}

\begin{abstract}
This research aims to prove that wide gap between theories and practices in terms of acquisition that should be positive to drive performance of the acquirer but the distinctive things happened in Indonesia was not according to the preliminary design planned. The failure acquisition of Semen Indonesia (SMGR) over Holcim Indonesia (SMCB) in 2018 due to what had been done during excessive capacity should be priority to strengthen interns than acting to intervene outside. This study elaborates a case study, mixed-type research, and presents by explanatory design. It comes to find that acquisition during excess capacity is a failure step taken by PT Semen Indonesia (Persero) Tbk. Many corporate steps are taken to a polish performance of the SMCBacquiree but so far failing and endangering the whole performance. To compensate and withhold the climb-down due to oversupply, the management engineering of market intervention had been done. Big portions of market's regions previously belong to SMGR had been handed over to SMCB to help increase its performance. The forced switching to polishing SBI's performance is hurting all of the holding's members. SBI enjoys improving market but at the same time endangers the performance of the whole groups of holdings. This research contributes to updating the present development of recent corporate actions of popular merger and acquisition are both previously labeled as the best corporate strategy for decades.

Keywords: Acquisition, PT Holcim Indonesia Tbk (SMCB), PT Solusi Bangun Indonesia (SBI), PT Semen Indonesia (Persero) Tbk (SMGR), Financial performance, Cement market, Corporate strategy, Failure innovation, Excess capacity
\end{abstract}

\section{Introduction}

The corporate action performed by the state-owned enterprise (SOE) Cement Holding of PT Semen Indonesia (Persero) Tbk (SMGR) at mid of November 2018 was a strategic step for the corporation, for the SOEs, and for the nation. This acquisition step was a first done by the SOE as the second done by Holding of Mining the Indonesia

(c) The Author(s). 2020 Open Access This article is licensed under a Creative Commons Attribution 4.0 International License, which permits use, sharing, adaptation, distribution and reproduction in any medium or format, as long as you give appropriate credit to the original author(s) and the source, provide a link to the Creative Commons licence, and indicate if changes were made. The images or other third party material in this article are included in the article's Creative Commons licence, unless indicated otherwise in a credit line to the material. If material is not included in the article's Creative Commons licence and your intended use is not permitted by statutory regulation or exceeds the permitted use, you will need to obtain permission directly from the copyright holder. To view a copy of this licence, visit http://creativecommons.org/licenses/by/4.0/. 
Alumunium (Inalum-it is now called MIND-ID) when acquired the gold and copper manufacturer Freeport Indonesia by December 2018. Transaction completed by SMGR over Holcim Indonesia (SMCB) recorded of US\$1.7 billion. This action was first shocking Indonesia's public as at the time Indonesia has experienced a shortage, deficit, and large of national debts. The first impression to SMGR was still powerful amid generally national business turbulence; the impression that confirmed as the corporation has never reported a loss as long as it is histories.

However, people are still questioning the corporate strategic taken by SMGR considering recent domestic and global cement markets that are in a downturn (Subiyanto 2020b). Even though Indonesia today is pouring with hundreds of project infrastructures but cement consumption otherwise sharply dropped and leaving with abundant domestic excess capacity. It was alarming that excess capacity during 2019 reached 38 million tons annually or similar with $34.55 \%$ total recent capacity in Indonesia.

As the acquisition was completed in 2018 to make the evaluation and measuring the effectiveness of overall SMGR's performance could be assessed by the first half of 2019 . The results are close with an earlier prediction that during H1-2019 the financial statements reported net profit to down $49.82 \%$ to Rp 480.82 billion (US\$34.34 million) compared to the same period of 2018. The depressed net income was caused due to an increase in financial expenses reaching threefold to Rp 1.5 trillion (US\$107.14 million), whereas in the same period in 2018, the costs were Rp 459.62 billion (US\$32.83 million). Meanwhile, the amount of long-term debts skyrocketed from $\mathrm{Rp} 4.87$ trillion (US $\$ 347.86$ million by the end of 2018) to $\mathrm{Rp} 20.38$ trillion (US $\$ 1,455.71$ million by June 2019). The new obligations as consequence has risen to $\operatorname{Rp} 7.06$ trillion (US\$504.29 million) from preliminary Rp 2.99 trillion (US\$213.57 million) in 2018. SMGR's total liabilities reach to an enormous Rp 45.06 trillion (US\$3,218.57 million), increase of $144.65 \%$ within only 6 months. The fall of SMGR's performance unavoidably occurred due to excessive acquisition of SBI in November 2018.

But, in contrast, SBI's financial performance in H1-2019 recorded losses Rp 278.51 billion (US\$19.89 million), though it significantly improved as in the same period in 2018, its lost even worsen to Rp 539.27 billion (US\$38.52 million). There was an improvement loss of $48.35 \%$. These losses were caused by a decrease of revenue by $2.02 \%$ yoy to Rp 4.52 trillion (US\$322.86 million) compared to the same period in 2018 of $\mathrm{Rp}$ 4.61 trillion (US\$329.29 million). Meanwhile, the general and administrative expenses for data and system maintenance spiked $212.51 \%$ yoy to Rp 111.87 billion (US\$7.99 million). The post is part of the Transitional Service and License Agreement (TSLA) between SMCB and Holcim Technology for the period 1 February 2019 to 31 January 2020 with the total cost of US\$16.7 million or Rp 233.8 billion (assuming an exchange rate of Rp 14,000/US\$). The TSLA agreement had ended in February 2020.

The other sides contribute to worsening SBI's performance is obligating to settle an increase of loan interest reached to $39.17 \%$ yoy to Rp 424.09 billion (US\$30.29 million). Long-term liabilities of debts to the third party surged $577.05 \%$ yoy, as by first half of 2019 was recorded Rp 7.83 trillion (US\$559.29 million) while compared at the same period in 2018 amounting to only Rp 1.16 trillion (US\$82.86 million).

In terms of financial indicators, SMGR's targets could not be achieved, only a matter of market share can be obtained by SMGR but remained slightly lower. By the period of H1-2019, SMGR's market share reached $42.80 \%$ with consolidated sales volume 
reaching 15.66 million tons domestically. Before the acquisition, SMGR's market share is about $39.6 \%$ while Holcim is at about $15.2 \%$ percent separately. The new ideal of market share should be at least $54.8 \%$ in total.

\section{Literature review}

Acquisition in tradition was executed due to needing for expansion, stacking bigger assets to accumulate revenue, and finally to grant the acquirer to get bigger profits. From this standpoint, the acquisition should be meant positive. But recently, as SMGR acquired SBI by take-over or acquisition, there is something significantly different. Unfortunately, the impact of the premium acquisition is looking to reduce performance, and finally making a lot of financial pressure on the acquirer.

In this research, there are several considerations to seek relevance theories of acquisitions. The corporate strategy primarily in the front row of the theories then followed by the technology management, process management, and many relating scientific disciplines in business and management. Some theory of business models, innovation, technological-driven consideration, and financial assessment is presented to bolster terms of acquisition might have to be done but in another side might be better restrained due to wait-and-see (Cao et al. 2018).

Amid economic weakening globally and without exception in Indonesia recently, the innovation of business model is encouraged or promoted in everywhere sectors. Within the national scale, Indonesia's government is recently also initiating to deprive a large number of conventional laws into a single law named omnibus laws. Several numbers of omnibus laws are now on the desk of the House of Representative (DPR) to be publicly discussed. The goal is simplifying regulations and the ultimate goal is keeping welfare for people. The innovation of laws is believed as the best pathway to reach the welfare's purpose and therefore is campaigning day-to-day. Innovation in the above terms is according to advice Metcalfe (2008) that focus on technology management. The laws that have been innovated will make implication directly to the people so that it must be coherently governed.

Similarly with Metcalfe (2008), Acur and Bititci (2010) presented a dynamic strategic management process (DSMP). It means almost complete models of frameworks, models, methodologies, tools, and relevant techniques are examined. DSMP is a tool seeking the best corporate strategy in dynamics uncertainty environment, while the corporate strategy is a matter of creating value independently for each business unit. Collocation is another variable that is important as part of corporate strategy (Toni and Tinchia 2010).

Kim (2010) stated that development is also imperative to enabling innovation of corporate strategy. Continuous technological change is unavoidably proven to drive expanding business size and help increase to be more modern efficiently, paving the way to dictate corporate strategy. In particular, Chou et al. (2010) introduced the importance of strategic information technology (IT) as part of decision support systems (DSS) to facilitate corporate strategy. Investment in IT's infrastructure is believed as a catalyst, therefore. This is because corporate strategy may lead to several scenarios in which a lessening of competition increases (Marshall and Parra 2019).

In terms of acquisition and mergers, it was still questioning in terms of effective and efficient. Is acquisition the best option to be taken or is defending intern solidity much 
better? Triebs and Pollitt (2019) was questioning, does acquisition increase plant productivity and deliver benefit for the acquirer? In contrast, it found acquisition has increased labor costs and in general increased total costs. Cost of integration is a must, also cost of coordination, costs due to sharing ideas, and costs during planning, and many more extra additional costs that may be incurred later. According to Horkoff et al. (2014) through his approach of business intelligence had warned from his research that business intelligence model (BIM) instead pushed of many additional costs might be incurred. In these focuses, costs of IT system implementations, and therefore IT infrastructure will become urgent and campaigned as the most important. Findings of Horkoff et al. (2014) was being supported by Calof et al. (2017) that previously proposing competitive intelligence $(\mathrm{CI})$.

The other technological driven based on IT, the conventional rather has also important and even more proof. Here is strategic business planning (SBP), an older version of popular management tool of the balanced scorecard (BSC) to allow managers to prepare and follow the organization strategic business planning (Souza et al. 2019).

Considering financial performance is also proposed as an important variable in executing an acquisition. Meanwhile, Nguyen (2018) has ever run a regression test to measure which better to diversify between assets, funding, and income. His research that is conducted in ASEAN regions from 2007 through 2014 resulted that incomediversified is far better than asset-diversified that implies an acquisition. Even more worse, the acquisition will drive the spirit of competition to be lower and potentially to operate under monopolistic, cartels, and or conglomeration (Ventouri 2018).

The most important when the acquisition will be chosen, it has to be sure before it has to be done; the acquirer has ever built a recent update of the business model. It must be rigorously simulated what position a host as an acquirer, and how operating companies which were acquired, all of them have to be synchronized as part of a new multinational company instead prior as a single company. Adapting their core of businesses is not only in terms of normative businesses but also must consider the relationship of the home country to the host country. Both of them must be counted (Cao et al. 2018) due to the home country is the origin place of acquirer while host country as placed of companies acquired. The brand is now further as one other of substantial determinants regarding the consumer-based brand, recommendation brand, building brand, understanding brand, and relationship blocks brand to identify core causes across countries that probably within coverage during acquisition (Chatzipanagiotou et al. 2019).

Finally, before this research comes to present works of literature that are coherent with this study, few factors of foreign market entries, exits, and re-entries are determined as considerations according to research conducted by Vissak et al. (2020). The acquisition is related to market-driven, both domestic and foreign, corresponding also with exit and or re-entry. The acquisition is a matter of intention in dominating the market to expand businesses.

In terms of cement business, there are a lot of empirical works of literature that presenting critics of acquisition, merger, or consolidated-market to avoiding accusation as a prior strategy to enactment monopoly and/or cartels. Akinyoade and Uche (2018) criticized the Dangote Cement as the dominant player in cement maker in Nigeria. The dominant role of the Dangote has created crony capitalists, arbitrarily claiming a 
certain program of the backward integration program (BIP) that allowing Dangote to take capital-intensive cement production business. Dahlstrom (2019) frankly stated that cooperation between cement makers create cartels and is common at the cement industries. Not only acquisition but also by cooperation with a short period of contracts, cement market will lose its fairness to customers, deliveries had been controlled, and the price was determined by vested-interest agreements. If cooperation only is potentially misused then acquisition will be more unimpeded to practically do cartels.

Vilakazi and Roberts (2018) found substantial evidence of anti-competitive conduct involves firms regarding their behavior in manipulating markets. The collusion firmly found in Southern and East Africa cement makers in exchange information for certain interested purposed, secret agreements, and lobbying government to distort facts for gaining private benefit. These conditions occurred due to rampant liberalization and acquisition in cement industries. Acquisition in these regions involves many collusive arrangements. The future of cement is uncertain due to severe competition but it is not a suggestion to do something illegally by acquisition each other (Dobbins 2018).

Furthermore, Paulus and Gay (2015) have ever suggested eluding acquisition as it was not proven to help increase productivity. Specifically, merger and or acquisition for Indonesian cement makers should be prohibited (Plunkett et al. 2006). It implied that Indonesia has ever determined price cement nationally (HPS) then deprived due spirit to build market fairness.

Last but not least, Brown (2018) has elaborated the patterns of industrial power in a big cement maker in Indonesia in the case of a major restructuring that took place after the crisis of 1997. It was found that weak corporate governance was implicated in the crisis of 1997, and these have associated restructuring including acquisitions and or mergers. This research suggests that restructuring or acquisition have often involved little more benefit than rescheduling of debts, improving productivity, and innovation; moreover, in the weak-economic-era as today globally happened.

\section{Research methodology}

This research builds by criticism theory, exhibits from the case and event study, and enriches data from observations. It begins with grounded theory to explain phenomenon concisely. All of them combined to build narrative explanatory employ with content analysis to build comprehensive interpretation. These qualitative methodologies (Denzin and Lincoln 2009) were chosen as a recent development acquisition of SMGR over SBI took place quickly and made a lot of substantially changing to the whole holding of SMGR's performance.

Data has been taken and treated from the secondary of the annual report and publicly published. Period data chosen for SMGR is before acquisition therefore annual report FY2018 to the H1-2019 a half year after acquisition. The commencing date of acquisition is November 2018. Data for SMCB has been taken also from the annual report that publicly published the same period of SMGR's data.

Analyzing data performs by spreadsheet processing, comparing graphs and tables, and presenting by prescriptive exploratory descriptive-narrative model. These methodologies are built by mixed-type combining quantitative and qualitative as well. 
Sharp analyzing is presented as if there are none other scientific arguments for comparison or none to make academic cover-both-side; therefore, the only point of view solely from consultant judgement that vested-interest are being single accommodated.

\section{Results and discussion}

\section{The collapse of SMGR's cash flow after the premium acquisition of Holcim}

To evaluate the results of a corporate strategic taken by corporation can be seen after a certain period of time. In this case, the financial report decomposed from the annual report based on H1-2019 was presented in this research. As commenced of acquisition by November 2018, therefore, the financial report of FY2018 is also employed. This is to examine earlier studies prepared by SMGR's management that acquisition is the best corporate action to drive corporate performance.

The acquisition was completely done by the end of 2018 worth US\$1.7 billion (Rp 26 trillion) for $80.06 \%$ shares including with all SBI's debts. This step was quite challenging as SBI has reported losses during the consecutive years of 2016, 2017, and 2018. Table 1 shows respectively losses Rp 758 billion (US\$54.14 million) and Rp 828 billion (US\$59.14 million), though its revenue reached Rp 10.377 trillion (US\$741.21 million in 2018) and Rp 9.382 trillion (US\$670 million in 2017). A cost component for SBI is brand royalty costing of $5 \%$ revenue worth of Rp 518 billion (US\$37 million in 2018) and Rp 469 billion (US\$33.5 million in 2017). So, even though, implies without the cost of royalty, SMGR still has lost worth Rp 240 billion (US\$17.14 million in 2018) and Rp 359 billion (US\$25.64 million in 2017).

By 2018, SMGR reported 10\% net profit of revenue and 6\% (2017), and it came to an average $8 \%$ of revenue. It meant that SBI would be a promising profit if its net-profit should reach to Rp 830 billion (US\$59.29 million), but in contrary it loses of Rp 758 billion (US\$54.14 million) with royalty cost and still lost of Rp 240 billion (US $\$ 17.14$ million) without royalty cost. There was not a positive return on investment (ROI) or without potentially profit for the acquirer, but SMGR has to finance acquisition to US $\$ 1.7$ billion ( $\operatorname{Rp} 26$ trillion). This was the first failure taken by the acquisition.

It came to read the balance sheet of H1-2019 compared to the end of 2018. It showed an increase of SMGR's assets from Rp 51 trillion (US\$3,642.86 million) to Rp 77 trillion (US\$5,500 million) or equal with an increase of Rp 26 trillion (US\$1.7 billion). This amount is precise to figuring total acquisition value instead of prior stated of US\$917 million.

Let start to assess debts. Total SMGR's debts which at the end of 2018 reached Rp 18 trillion (US\$1,285.71 million) had risen to Rp 45 trillion (US\$3,214.29 million) or an

Table 1 Financial evaluation of SBI

\begin{tabular}{lll}
\hline & FY2018 & FY2017 \\
\hline Lost & Rp 828 billion (US\$59.14 million) & Rp 758 billion (US\$54.14 million) \\
Revenue & Rp 10.377 trillion (US\$741.21 million) & Rp 9.38 trillion (US\$670 million) \\
Brand royalty 5\% & Rp 518 billion (US\$37 million) & Rp 469 billion (US\$33.5 million) \\
Assets & Rp 14.447 trillion (US\$1,031.93 million) & \\
Book value & Rp 6.135 trillion (US\$438.21 million) & \\
DER of LafargeHolcim & 0.99 & \\
\hline
\end{tabular}

Source: Author's taken based on the published annual report 
increase of debts of Rp 27 trillion (US\$1,928.57 million). It meant SMGR has financed its acquisition with debts worth of Rp 27 trillion (US\$1,928.57 million). Interestingly, from an official financial report at the period, the interest rate set was $9 \%$. It is quite financially questioning as financing with an interest rate of $9 \%$ but without expectation to get ROI. Commonly, the ROI should be higher than the interest rate to accordingly have ability to pay-off debts. This was the second failure by SMGR.

Could the ROI acquisition over SBI be increased to $9 \%$ or more than $900 \%$ than originally nearly $0 \%$ ? It will be an increase of margin (ratio of net-profit to revenue) and as long as the historical achievement of SMGR which at average $8 \%$, it can be immediately said impossible. Another alternative to increase total revenue for $900 \%$ is also impossible given the weak macroeconomy either domestically or globally. Even more, SMGR is the ruler of the cement market with statistically designed of total market share should be to at least 55\% domestically. Simply, SMGR will violate anti-monopoly law 1999.

It was to conclude that acquisition of SMGR over SBI is a lost acquisition project or impossible mission. Lost at the time made of acquisition and lost to perform maximum achievement as weakening markets and worsen due to the acquisition has been done at the time excess capacity of cement domestically and globally. It was an expensive acquisition even more in Indonesia. This is the third failure taken of SMGR.

How expensive acquisition over SBI can be presented as follows. The total asset value of SBI by end of 2018 was Rp 14.447 trillion (US\$1,031.93 million). Due to portion of the acquisition of SMGR is $80.06 \%$ shares meant equal to Rp 11.5 trillion (US $\$ 821.43$ million). So, if it compared with the value by the date of acquisition by end of 2018 worth of Rp 26 trillion (US\$1.7 billion), it would be 2.26 times of normal market price or $126.08 \%$ higher than normal market price. This is a distinctive acquisition-as the SBI is a traditional loss company-with premium prices far above the market price is certainly hurting the acquirer and benefiting for shares holders of companies acquired. It is hurting to SMGR - an SOE-but otherwise benefiting for SBI, a private company. This is the fourth failure taken by SMGR.

Let assess in the way of book value. The book value of SBI by end of 2018 was $\mathrm{Rp}$ 6.135 trillion (US\$438.21 million). The portion of SMGR with $80.06 \%$ shares was acquired then equal to $\mathrm{Rp} 4.912$ trillion (US\$350.86 million). So, the transaction of acquisition will be 5.29 times of book value as acquisition priced US\$1.7 billion ( $R p 26$ trillion).

Discussing based on debts is also hurting. As mentioned in Table 2, the acquisition has been financed by additional debts, then the total debt of SMGR has increased in debt to equity (DER) ratio which was originally 0.56 to 1.41 . If we compared with Holcim's headquarter of LafargeHolcim showed a better DER ratio to 0.99 (see Table 1). It poses that this acquisition increases risks to SMGR as debt with consequence bankruptcy demand from creditors if SMGR has failed to pay. Table 2 shows that shortterm debts of SMGR have increased from Rp 8 trillion (US\$571.43 million) became Rp 14 trillion (US\$1,000 million) or increased of Rp 6 trillion (US\$428.57 million), while long-term debts have increased from Rp 10 trillion (US\$714.29 million) became Rp 31 trillion (US\$2,214.29 million) or increased of Rp 21 trillion (US\$1.5 billion). The increase of this shows that SMGR is not just using the long-term debts for the acquisition, but even more, SMGR is also using short-term debts for this takeover. 
Table 2 SMGR's lists of debts

\begin{tabular}{lll}
\hline & FY2018 & FY2017 \\
\hline Net proportion & 10\% total revenue & $6 \%$ total revenue \\
Proportion rights over SBI & Rp 664 billion (US\$47.43 million) & $\mathrm{n} / \mathrm{a}$ \\
Total debts & Rp 45 trillion (US\$3,214.29 million) & Rp 18 trillion (US\$1,285.71 million) \\
Interest rate & $9 \%$ & \\
DER & 1,41 & 0,56 \\
Short-term debts & Rp 14 trillion (US\$1,000 million) & Rp 8 trillion (US\$571.43 million) \\
Long-term debts & Rp 31 trillion (US\$2,214.29 million) & Rp 10 trillion (US\$714.29 million) \\
\hline
\end{tabular}

Source: Author's taken based on the published annual report

The consequence of increasing debts is increasing payment of interest. It can be seen from Table 3 that interest payment in H1-2018 was Rp 336 billion (US\$24 million), but at H1-2019, it had skyrocketed to Rp 1.272 trillion (US\$90.86 million), or an increase of Rp 936 billion (US\$66.86 million). The increase of payment interest will be directed to impact on cash flow. It shows during H1-2018 operating cash flow still Rp 1.5 trillion (US\$107.14 million), but it became minus Rp 130 billion (-US\$9.29 million) by H1-2019. Due to payment of interest also results in lower net profit. By H1-2018 if net profit reported Rp 965 billion (US\$68.93 million), then it declined to Rp 481 billion (US\$34.29 million) by H1-2019. The pressure was reached by $50 \%$ or lost at Rp 484 billion (US\$34.57 million). This is the fifth failure taken by SMGR.

The decline of profit is much lower than the increase of interest payment as mentioned above which amounted to Rp 936 billion (US\$66.86 million). So, SMGR will make massive savings in other expenses. One of which must be done is retaining payment of welfare of employees as like bonuses and or incentives. If that is the case, SMGR's employees will feel it (Subiyanto 2020c).

Improvement in other sides can be seen for SBI. SBI in a few years before being acquired by SMGR always suffered losses. In H1-2018, there were reported losses of Rp 539 billion (US\$38.5 million), and still losses at H1-2019 to Rp 279 billion (US\$19.93 million). It meant, under SMGR, SBI's performance improved significantly although it still suffered losses. But seeing SMGR's profit decreases heavily, it can be read that SMGR had sacrificed greatly to improve SBI. This is the result of acquisition that funded by debts, and this is the sixth failure taken by SMGR.

It comes to seek alternatives, and there are rooms to solve the issues. Total assets of SMGR by end of 2018 were Rp 68 trillion (US\$4,857.14 million), if SMGR put right

Table 3 Evaluation of $\mathrm{H} 1$ financial statement of SMGR

\begin{tabular}{|c|c|c|}
\hline & H1-2019 & H1-2018 \\
\hline Assets & Rp 77 trillion (US\$5,500 million) & Rp 51 trillion (US\$3,642.86 million) \\
\hline Debts' interest & Rp 1.272 trillion (US\$90.86 million) & Rp 336 billion (US\$24 million) \\
\hline Total debts & Rp 45 trillion (US\$3,214.29 million) & Rp 18 trillion (US\$1,285.71 million) \\
\hline Cash & -Rp 130 million (-US\$9.29 million) & Rp 1.5 trillion (US\$107.14 million) \\
\hline Net profit & Rp 481 billion (US\$34.29 million) & Rp 965 billion (US\$68.93 million) \\
\hline Impact to SBI & -Rp 279 billion (US\$19.93 million) & -Rp 539 billion (-US\$38.5 million) \\
\hline Comment & SBI improved but SMGR sacrificed & \\
\hline
\end{tabular}

Source: Author's taken based on the published annual report 
issues to pay the entire value of the acquisition of Rp 26 trillion (US\$1.7 billion), it will only require the issuance of additional shares of $38 \%$. But to be remembered, every single state-owned enterprise has obliged to meet certain laws that shares of Indonesia's government should be at least $51 \%$. The second reason is the ROI problem. The priceearnings ratio (PER) of SMGR is about 25 that can be read that investors expect to get ROI of $100 / 25$ or at least $4 \%$. By this, if issuing additional shares worth Rp 26 trillion (US\$1.7 billion) then shareholders of SMGR will demand an additional profit of SBI amounted to $4 \%$ or Rp 1.04 trillion (US\$74.29 million). It is certainly not possible to do because the ROI projected of SBI as mentioned above is below than $0 \%$.

It can be concluded that acquisition over SBI done by SMGR is a lost transaction since the beginning. This is a traditional thing we assumed that phenomenon of pseudo or myopia or shadow is still adhering at every state-owned enterprises (SOEs) in Indonesia generally. It has done polishing performance to make a good report as far as possible as they did, in any way, due to denying facts that at the beginning was a mistake.

Figure 1 best describes explanatory given to easily understand comprehensive figures post-acquisition over SBI done by SMGR. It is showing within the box-marking of the date of acquisition-the increasing of many indicators. Total debts have increased, DER, long-term debts, short-term debts, while in contrast, a graph of net profit experienced downturn gradually. This is fostering arguments that acquisition is not merely of business instinct or agility to respond business call, but rather acquisition is scientific knowledge, concrete, employing with measurement of methodologies that empirically proven and examined. See outside, when market possibly immediately does to take over, but in contrary, restrain but bolster internally, intern innovation is much useful than acquisition.

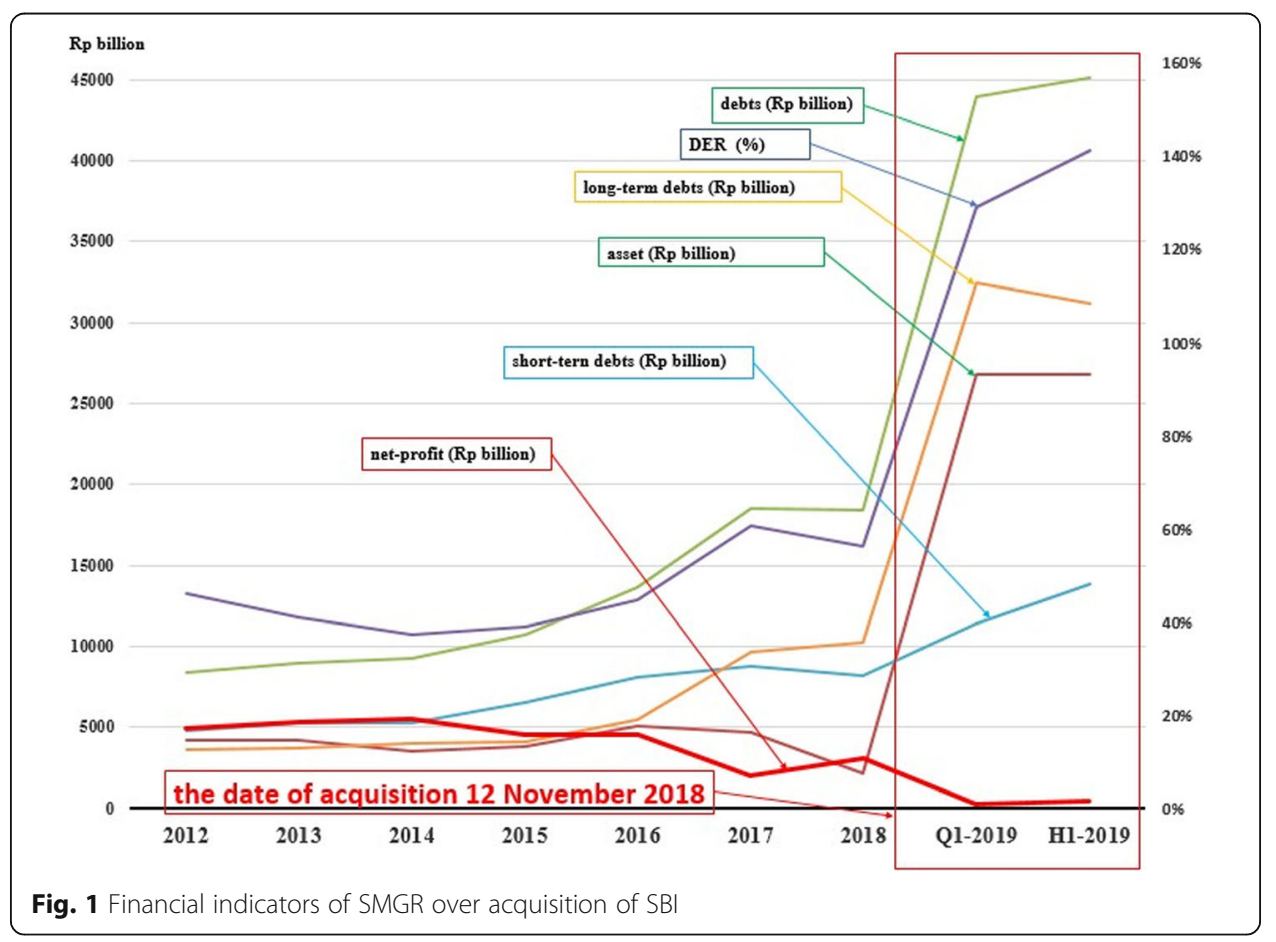




\section{Conclusions, implication, and limitations of the research Conclusions}

Although in terms of market share, the acquisition of SBI proves that SMGR continues to lead market majorly; however, the maximum performance achieved SMGR in 2013 is hard to recover back again. At that time, total cement absorption was 58.01 million tons, while installed capacity was 65.8 million tons. The utilization rate of cement plants is impressively high at $88.16 \%$.

In contrast, by the end of 2019, the investment of new cement factories was like a flood so that capacities had exponentially increased. Total roadmap of national cement producers is swiftly changing. Installed capacity rose to 128.95 million tons while consumption only 76.1 million tons in 2019, the utilization rate is gradually declining below than $59.02 \%$. The only construction sector of infrastructure projects that previously expected to absorb cement bigger, in fact, does not come true. There are already 15 new cement branches which are present in Indonesia and are all already operational.

The only concern for Indonesia's cement makers are penetration of China's cement producers. If in 2013 the Chinese cement plants had the capacity of 1.75 million tons from Semen Puger (PT Semen Imasco Asiatic) and Semen Merah Putih (PT Cemindo Gemilang), by the end of 2019 installed capacities had reached of 37.1 million tons annually and dramatically increasing. The capacity ratio of China's cement factories to national capacities is 2.58\% (2013), but at H1-2019 it has reached $28.77 \%$. Note that the total installed capacity of national cement producers in 2019 was 128.95 million tons.

This abundance of cement products has caused the average selling price (ASP) in Indonesia to continue to decline sharply. If it was originally $\operatorname{Rp} 900,000 /$ tons (US\$64.29/tons), then it dropped $6.89 \%$ and continuing. Chinese cement branches, in contrast, have set ASPs lower to $22.22 \%$ with an average price of US\$50 per ton. By 2020, the price of cement online for the size of $40 \mathrm{~kg} / \mathrm{bags}$ made from China is about Rp 34,000/bags (US\$2.43/bags) while local cement is set for Rp 51,000/bags (US $\$ 3.64 /$ bags). The price of Chinese cement which is only $66.67 \%$ of local price has been accused to undertake unfair predatory pricing.

A recent update of the market and current disruptive situation of national cement market failed to be anticipated by SMGR and insisted to proceed acquisition over SBI. SMGR still assumes that market remains linear with optimistic profit margins high above $20 \%$ as usual. What has been abstained and calculated is the massive tide of foreign cement investments into Indonesia. Barrier arguments that investment of cement plants require large capital, technology, human resources, and resources are wiped by the investors considering abundant of profit margins. Elsewhere, ease of doing businesses are campaigned by Indonesia's government massively. Licensing of mining area has been simplified, a land acquisition that traditionally became the heaviest barriers for investment are severely getting more attention, resulting in improvement processes of land acquisition.

But it was over and passed, the choice is back to the SMGR. The acquisition of SBI by SMGR was recorded not at a discount price despite its historical losses since 2016. The November 2018 acquisition transaction was worth US\$ 1.7 billion (Rp 26 trillion) for four cement plants, 33 ready-mix factories, and a couple of quarries (mines). Many SMGR's efforts have been done to finance the acquisition of SBI by generating several 
new debts of US\$1.28 billion (Rp 18.97 trillion) from several consortium banks of the BNP Paribas, Deutsche Bank AG of Singapore Branch, Maybank Kim Eng Securities Ltd., MUFG Bank, and Standard Chartered Bank. These debts were recorded in financial statements in Q1-2019 worth of Rp 25.69 trillion (US\$1,835 million) and resulting interest expense as one the suppressors of SMGR's net profit down to $49.82 \%$ or the worst as long as histories of SMGR.

What can be learned from the acquisition over SBI of SMGR as an SOE should increase capacity by an investment mechanism rather than by acquisition that instantly. Investment is a fundamental economic driver because there is real involvement for Indonesian people. SMGR can contribute to reducing the national unemployment rate, becoming a driver for economic growth in Indonesia that today is uncertain, contributing to the societies, triggering new economic creativity that currently is so weak, and as contributors of new investment in Indonesia. The building of capacity and increasing the scale of companies by acquisitions are pseudo methods that characterize industrial egoism. Even more, SMGR is notably a state-owned enterprise that should take responsibility for the social sector.

Amid spirit to recover weakening domestic economy which is still lame, the government needs to be firmed that SOEs as an agent of change should not use acquisition mechanism in its corporate strategy. Rather, the SOEs must apply a more conservative mechanism that does not merely only seek big pseudo profits but cannot be felt by surrounding societies. The communities' interests should be considered more important according to laws as primary duty every single SOEs.

\section{Implications for policy and practices}

There is valuable learning and experiencing from Indonesia that taking deeper and longer consideration in executing a leap transformation is the most imperative and empirically proven. The acquisition SMGR over Holcim Indonesia (it is now said SBI) was done less than 6 months consideration to decide and have claimed as an urgent by 2018. This was rather a swift action considering the enormous value of debts US $\$ 1.7$ billion and becoming big burdens for the SMGR's performance now.

It is also a valuable knowledge contribution that acquisition during excess capacities while supporting determinants as, like markets, growth economy, and others were unfavorable is a great mistake taken ever done of SMGR and delivering novelty in recent research of businesses and corporate strategy.

A simple message for Indonesia's government that appointing executives of Board of Directors and or Board of Commissioners in SOEs must be deliberately selected based on competence, capacity, integrity, and must understand characteristic and nature of every SOEs' business model rather than politically inclined like and dislike, subjective, transactional, and vested of interest.

\section{Theoretical and practical implications}

The world mergers and acquisitions (M\&A) is always changing and dynamic. According to report Refinitiv (September 2019), the global M\&A transactions fell 16\% yoy to US\$ 729 billion in the third quarter of 2019, the lowest since 2016. Causes of conditions due to (1) the US-China trade war, (2) economic uncertainty, (3) Hong Kong 
rallies, and (4) the British Brexit. The situations no longer improve as globally in the second quarter of 2020, the M\&A also dropped 52\% to US\$ 516.6 billion across 9129 deals (Beltran 2020).

In cement sectors, the last biggest acquisition of giant cement makers happened to the Holcim and LaFarge in April 2014. The goal of the merger and acquisition is to strengthen the hegemony of the global cement market. The acquisition, which was valued at US\$ 55 billion, had been said to be the biggest at the moment to reduce costs, especially fuel price increases in 2008. Holcim is the world's third-largest and largest cement manufacturer from Switzerland with a production capacity of 174 million tons. While LaFarge (France), the number two production capability in the world with a capacity of 205 million tons per year.

Before the merger and acquisition LaFargeHolcim, the champion of the world's largest cement manufacturer was China's Anhui Conch with a capacity of 217 million tons per year. But after these two European cement giants merge, their acquisition capacity will accumulate to 379 million tons per year and become the biggest cement manufacturer to now.

The increase spirit of acquisition is in line with Weston et al. (2004), Thompson et al. (2007), (Baye 2006), Besanko et al. (2007), and Chien et al. (2005) who have viewed the acquisition is the only effective corporate strategy at the time.

But the development is rapidly triggering substantial changes and proven that executing the acquisition strategy was not solely effective. In contrast, the acquisition is a trap for the business that not carefully operated and managed.

The case of SMGR's acquisition in Indonesia is the best experience not to be followed it was warned previously by Cao et al. (2018) to restrain due to better develop business model first. Metcalfe (2008) suggests to focus technology management, Acur and Bititci (2010) advise to utilize dynamic strategy, Toni and Tinchia (2010) to strengthen corporate strategy likewise suggest delivered by Marshall and Parra (2019), business intelligent according to Horkoff et al. (2014), while Calof et al. (2017) prefer in developing IT. Further, many different strategies can be applied to win the competition as advice by Souza et al. (2019) who recommend improving organization, and Nguyen (2018) to make better at the financial side. At the negative perspective, Ventouri (2018) who warned of the negative impact of conglomeration, Vissak et al. (2020) in dominating markets, Brown (2018) based on crisis-led in Indonesia due to conglomeration, and Subiyanto (2020b) who found that cement markets are not driven solely by national economic growth.

\section{Limitations and future avenues of research}

The data for this research were collected from the publicly annual reports that were not easy to be found. The findings, however, cannot be generalized beyond the cement industry. Furthermore, it is well known that to improve acquired performance, it could be done in many ways and unfortunately, it will be hard to find and be detected.

The way to develop shadow performance could be by market approach, organizational change, procurement or project (Subiyanto and Suyoto 2020; Subiyanto 2020a), and many strategic steps that wrapped as corporate actions or as operational expenses.

These are challenging for future researchers worldwide, but at the same time, it is opening chance to do further avenue prospective research. 


\section{Abbreviations}

SMGR: PT Semen Indonesia (Persero) Tbk - ticker code in Jakarta Stock Exchange (BEI); SMCB: PT Semen Cibinong or PT Holcim Indonesia or PT Solusi Bangun Indonesia-ticker code in Jakarta Stock Exchange; SOE: State-owned enterprises; MIND-ID: Mining Industry Indonesia, the new corporate name of PT Indonesia Alumunium (Inalum); TSLA: Transitional Service and License Agreement; H1: First semester; DPR: Indonesia House of Representatives; FY: Full year; DER: Debt to equity ratio; ROI: Return on investment; ASP: Average selling price; M\&A: Mergers and acquisitions

\section{Acknowledgements}

The author is grateful to the scholar Iman Supriyono and researchers at the Employee Union of Semen Indonesia (SKSI) who inspired and helped me to identify and evaluate of the annual report that is fully accounted. The author also personally thanks the Widya Mandala Surabaya Catholic University (UKWM) for supporting our research. Thanks also to the anonymous reviewers that help improve this research.

\section{Author's contributions}

This research is solely conducting by the Author.

\section{Author's information}

The author is a lecturer that teaches corporate strategy at the Widya Mandala Surabaya Catholic University (UKWM) Surabaya, Indonesia.

\section{Funding}

This research received no specific grant from any funding agency in the public, commercial, or not-for-profit sectors.

\section{Availability of data and materials}

The raw data came from the published annual report that publicly is easily accessed.

\section{Competing interests}

The author declares no competing interests.

Received: 1 April 2020 Accepted: 14 September 2020

Published online: 24 September 2020

\section{References}

Acur, N., \& Bititci, U. (2010). Managing strategy through business processes. Production Planning and Control, $309-326$.

Akinyoade, A., \& Uche, C. (2018). Development built on crony capitalism? The case of Dangote Cement. Business History, 833858.

Baye, M. R. (2006). Managerial Economics and Business Strategy. New York: McGraw Hill.

Beltran, L. (2020). Private equity. Retrieved from https://www.barrons.com/: https://www.barrons.com/articles/mergers-andacquisitions-dropped-83-in-the-u-s-because-of-covid-51594036800

Besanko, D., Dranove, D., Stanley, M., \& Schaefer, S. (2007). Economics of Strategy, (4th ed.). Wiley.

Brown, R. A. (2018). Conglomerates in contemporary Indonesia: concentration, crisis and restructuring. South East Asia Review, 378-407.

Calof, J., Richards, G., \& Santilli, P. (2017). Integration of business intelligence with corporate strategic management. Journal of Intelligence Studies in Business, 62-73.

Cao, L., Navare, J., \& Jin, Z. (2018). Business model innovation: How the international retailers rebuild their core business logic in a new host country. International Business Review, 543-562.

Chatzipanagiotou, K., Christodoulides, G., \& Veloutsou, C. (2019). Managing the consumer-based brand equity process: A cross-cultural perspective. International Business Review, 328-343.

Chien, W., Shih, S., \& Chu, P. Y. (2005). Business Growth Strategies for Asia Pacific. Singapore: Wiley.

Chou, T., Robert, R., \& Powel, P. (2010). An empirical study of the impact of information technology intensity in strategic investment decisions. Technology Analysis \& Strategic Management, 325-340.

Dahlstrom, M. (2019). The foundations of cooperation: building cartels in the Nordic cement industry and beyond, 1890 1947. Scandinavian Economic History Review https://doi.org/10.1080/03585522.2019.1703803.

Denzin, N. K., \& Lincoln, Y. S. (2009). Handbook of Qualitative Research. California: Sage Publication.

Dobbins, C. (2018). The cement industry: in search of its future... an old industry takes on a new look. Financial Analysts Journal, 21-26.

Horkoff, J., Barone, D., Jiang, L., Yu, E., Amyot, D., Borgida, A., \& Mylopoulos, J. (2014). Strategic business modeling: representation and reasoning. Software and Systems Modeling, 1015-1041.

Kim, L. (2010). Technology policies and strategies for developing countries: lessons from the Korean experience. Technology Analysis \& Strategic Management, 311-324.

Marshall, G., \& Parra, A. (2019). Innovation and Competition: The Role of the Product Market. International Journal of Industrial Organization, 221-247.

Metcalfe, J. (2008). Evolution, technology, policy and technology management. Prometheus, 29-35.

Nguyen, T. (2018). Diversification and bank efficiency in six ASEAN countries. Global Finance Journal, 57-78.

Paulus, J. D., \& Gay, R. S. (2015). Analysis: U.S. mergers are helping productivity. Challenge. https://doi.org/10.1080/05775132. 1987.11471162

Plunkett, H. J., Morgan, W. E., \& Pomeroy, J. L. (2006). Regulation of The Indonesian Cement Industry. Bulletin of Indonesian Economic Studies, 75-102.

Souza, J., Falsarella, O., \& Correa, C. (2019). Corporate strategic management: a proposal for the use of sustainability performance indicators. International Journal for Innovation Education and Research, 241-258. 
Subiyanto, E. (2020a). Assessing total logistics costs: case study during the execution of cement projects in Indonesia. International Journal of Applied Logistics, 10(2), 45-61. https://doi.org/10.4018/JAL.2020070103.

Subiyanto, E. (2020b). The relationship of cement consumption and economic growth: an updated approach. European Research Studies Journal, 280-295. https://doi.org/10.35808/ersj/1638.

Subiyanto, E. (2020c). Violating labour's rights, a failure understanding establishment of SOEs Holdings: evidence at the stateowned enterprise cement holding of PT Semen Indonesia (Persero) Tbk. Technium Social Sciences Journal, 7(1), 1-17 ISSN: 2668-7798. https://doi.org/10.47577/tssj.v7i1.418

Subiyanto, E., \& Suyoto, Y. T. (2020). Determining Value of Logistics Costs in Projects; Empirical Findings based-on Executing Several Cement Projects in Indonesia. Heliyon, 6(7). https://doi.org/10.1016/j.heliyon.2020.e04352.

Thompson, A. A., Strickland, A. J., \& Gamble, J. E. (2007). Crafting \& executing strategy; the quest for competitive advantage, concepts and cases. New York: McGraw Hill.

Toni, A., \& Tinchia, S. (2010). New production models: A strategic view. International Journal, 4721-4741.

Triebs, T., \& Pollitt, M. (2019). Objectives and incentives: evidence from the privatization of Great Britain's power plants. International Journal of Industrial Organization, 1-29.

Ventouri, A. (2018). Bank competition and regional integration: Evidence from ASEAN nations. Review of Development Finance, $127-140$.

Vilakazi, T., \& Roberts, S. (2018). Cartels as 'fraud'? Insights from collusion in southern and East Africa in the fertiliser and cement industries. Review of African Political Economy, 369-386.

Vissak, T., Francioni, B., \& Freeman, S. (2020). Foreign market entries, exits and re-entries: the role of knowledge, network relationships and decision-making logic. International Business Review, 1-22.

Weston, J. F., Mitchell, M. L., \& Mulherin, J. H. (2004). Takeovers, restructuring, and corporate governance. New Jersey: Prentice Hall.

\section{Publisher's Note}

Springer Nature remains neutral with regard to jurisdictional claims in published maps and institutional affiliations.

\section{Submit your manuscript to a SpringerOpen ${ }^{\circ}$ journal and benefit from:}

- Convenient online submission

$\checkmark$ Rigorous peer review

- Open access: articles freely available online

- High visibility within the field

- Retaining the copyright to your article 